study and collection. The Sofia called at Thurso for coal on Sunday and left on Tuesday.

IN connection with Prof. Fries' suggestion of colonising Greenland by mountain Lapps, to which we referred last week, we learn that Baron Nordenskjöld takes with him to Greenland two Lapps from Jockmock, to give their opinion of the country. One of them is thirty, and the other thirty-three years of age.

WE learn from the last annual report of the East Siberian branch of the Russian Geographical Society that this Society, which has contributed so largely to the increase of our knowledge of Siberia, is beginning to recover from the losses it sustained during the great fire at Irkutsk. Private subscriptions have been raised for the reconstitution of the library and museum to the a inount of $2170 l$, and both are in a fair way of development. The li irary already has about 4000 volumes, but is in great want of foreign geographical publications, and makes an appeal to the yeographical societies throughout the world to send their publi cations and, if possible, series of former publications, which ought to be addressed to the Secretary of the East Siberian branch at Irkutsk. The chief occupations of the Society were the geological exploration east of Lake Baikal, by M. Chersky, who has already published a map of the western coast of the lake; archæological researches as to the prehistoric inhabitants of Siberia, by MM. Agapitoff, Khangaloff, Witkovsky, and Bogolubskiy ; and the part it took in the organisation of the Arctic Meteorological Station at the mouth of the Lena, and of a series of four intermediate stations between Irkutsk and this station. This last scheme could not be realised in full, but two stations have already been opened at Verkholensk and at Preobrajenskoye. The last number of the Fournal of the Society contains, besides the annual report and the proceedings, a list of new determinations of latitudes and longitudes in Transbaikalia a notice on Shamanisur with Yakuts; a paper on the populations of the basin of the Amur, according to Prof. Schrenck; a paper on the inscriptions on stones and rocks in the district of Minusinsk ; and several notes, on the Lena Meteorological Station, on the Usuri segion, \&c.

Petermann's Mittheilungen for May co tains a paper by $\mathrm{Mr}$. Carl Bock describing a journey recently made by him from Bankok to the frontiers of the independent Shan States. He travelled along the Menam River in a boat given him by the Siamese Government, as far as Raheng, where he diverged into the Me Ying. He then proceeded partly by the river, partly by land through Lakon and Lampun, to a town which he calls Tschengmai, but which is more generally known as Kiangmai, or Zimmé. This place, which is the capital of the Shan State tributary to Siam, is an important point in Mr. Colquhoun's proposed railway from Rangoon and Moulmein, into southwestern China. It formed the proposed terminus, too, of that gentleman's recent journey through Yunnan and the Shan States. Mr. Bock described it as a fortified town of about 700,000 people, lying in a fertile plain of uninterrupted rice fields, about 500 yards from the Me Ping, which is here 400 feet wide. Even now it is of great political and commercial importance, as it controls the trade of these regions both with Siam and with British Burmah. The teak forests of the States he describes as almost inexhaustible, especially higher up near the Meikong, where, however, it is not yet known whether the lumber can be easily floated down to the sea. For this purpose Mr. Bock recommends a careful survey of the various rivers and their tributaries. From Zimme he continued his way higher up to Kiangtsen, in the valley of the Meikong, and on the borders of the independent Shan States. It was his original intention to travel through these States into Yunnan, as it was Mr. Colquhoun's to travel through them from Yunnan, southwards. Failing this, he returned to the Me Ping, with the object of tracing this river to its source. He was prevented from carrying out either project by the native hostility, which, we regret to say, Mr. Bock himself did much to intensify, if not arouse, by his indiscreet behaviour. It would be inconceivable, if we did not have it on his own testimony, that any traveller among a people who, as he was specially warned, disliked even the Siamese, and absolutely hated any white man, should so far forget all discretion as to enter a populous town and "out of his own hand," as he describes it, take posses. sion of the court of justice, and assault with a stick the official who endeavoured to prevent this unjustifiable trespass. He was punished by several days' imprisonment, but it is unfortunate for the cause of science that the hostility thus carelessly and wilfully aroused should have put a speedy termination to a journey full of promise. Mr. Bock, however, has shown beyond doubt that a railway from Bankok to the Shan frontiers is a possibility. It would pass through populous and rich districts in the valleys of the Menam and Me Ping. $\mathrm{He}$ says that no one who has not visited Zimmé can understand how extensive the trade of the place is, and his proposed railway would place the Laos States in direct communication with the sea, and attract the commerce not only of the Shan States, but also of Yunnan. These are exactly the arguments by n hich Mr. Colquhoun supports his scheme for a railway to Rangoon. Let $\mathrm{u}$; hope that in days to come, when this colossal project is an accomplished fact, there may be no dispute as to the originator of the idea of attracting the trade of south-western China to the sea by means of a railway through the Shan States.

\section{A NEW FORM OF SEISMOGRAPH}

N UMEROUS forms of seismometers have from time to time been invented, and having these various instruments, it may be asked why there is any necessity for a new form, and I can best answer this by quoting from a report of a committee of the British Association of 1872, as follows :- "Some simple and cheap method of indicating earthquake movement is thus much to be desired-any apparatus for the purpose should occupy small space, be little liable to derangement, capable of being put up in any apartment not of special construction, and its indications such as any intelligent person could easily interpret and readily note."

Now none of the instruments yet invented fulfil these conditions, and hence I bring before you one which is of the very simplest nature.

The idea of the instrument I propose was suggested to me by the aseismatic arrangement designed by my father, $\mathrm{Mr}$. David Stevenson, for averting damage to buildings and lighthouse appara' us in countries subject to earthquakes (Trans. Roy. Scot. Soc. Arts. vol. vii.)

The instrument is shown below, and consists of a ground and polished glass plate (A), about 5 inches square, placed level (once for all), on which rest three accurately turned ivory balls about $1 \frac{1}{2}$ inch diameter, and on the top of these

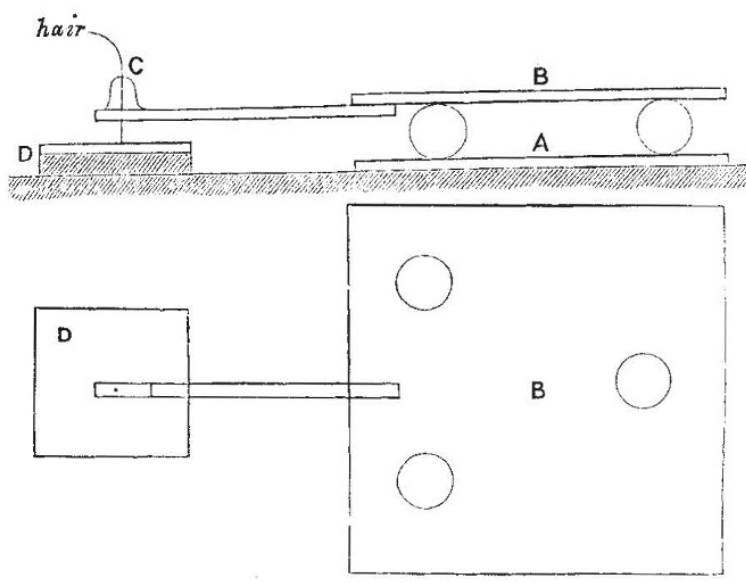

balls is placed a plate (B) similar to the lower, but having attached to it a projecting arm with a long vertical hole pierced through it. Through this hole passes a steel needle (c) with a fine point, which rests by its own weight on a lampblack surface formed on the plate D. A hair about 2 inches long should be fixed to the eye of the needle to assist in adjusting it. The instrument thus becomes a pendulum of infinite length, so that whenever there is any movement of the ground, and therefore of the lower plates, the top plate with its arm and needle attached remain practically steady, and the point of the needle therefore marks on the lampblack surface the amount of motion and the direction in which the lower plate is moved. This instrument, it will be observed, fulfils all the requirements mentioned in the report of the committee of the British Associa-

I Abstract of paper read before the Royal Scottish Society of Arts, February 13, 1882, by Charles A. Stevenson, C.E., Edinburgh. 
tion, and can be made more or less sensitive. It is impossible from a mere description to form any conception of the efficiency of the apparatus, nor has it been tried by any earthquake, but the instrument before you having been erected on the gable of a dwelling house during the past year, repeatedly registered the shaking of the gable to the amount of I-I6th of an inch.

\section{UNIVERSITY AND EDUCATIONAL INTELLIGENCE}

Cambridge.-The Museums and Lecture Rooms Syndicate have just i-sued their annual report, in which they mention the high value of the present of the late Prof. Balfour's scientific instruments and library to the University by his family, and again emphasise the necessity existing for a new chemical laboratory. Mr. Clark records the mounting of the fine male Indian elephant's skeleton in the Zoological Museum, received in an exceedingly complete state last year in consequence of its careful preparation by Mr. A. Haly of the Colombo Museum. The animal was shot by Mr. Le Mesurier of the Ceylon Civil Service; its height was nine feet. A specially interesting skeleton of the adult Gangetic Dolphin has been presented by Sir J. Fayrer. Mr. A. P. Maudslay, M.A., of Trinity Hall, has rleposited in Mr. Clark's care a large portion of his ethnological collection made in Fiji and adjacent islands; these are almost certain to be presented to the University at no distant date. The Curator in Zoology (Mr. A. H. Cooke) bas catalogued and arranged the British species in the MacAndrew collection. Its completeness may be judged by the facts that of 6 recorded species of Bracbiopoda this contains 5 ; of 159 marine Conchifera this contains 146 ; of 248 marine Gasteropoda this contains 208; of 125 land and freshwater shells this contains II4 A recent appeal to add missing species has already resulted in the presentation of fourteen species by Mr. J. T. Marshall.

Dr. Michael Foster reports an average class of about 100 in Elementary Physiology, and of over 20 in advanced Physiology, in the three terms of the past year. Additional lecture room accommodation is much needed for these large classes.

The morphological work begun by the late Prof. Balfour has been continued on the same lines by Mr. Adam Sedgwick, Mr. W. H. Caldwell and Dr. Hans Gadow as lecturers, and Mr. Walter Heape and Mr. W. F. R. Weldon as demonstrators. In the Lent Term of this year 63 students attended the elemen tary class, and 26 the advanced classes. Five students have been engaged in original work. Mr. A. J. Balfour, M.P., has offered to give annually a sum sufficient to defray the cost of the complete series of scientific journals taken in by his late brother.

Dr. Vines has carried on practical instruction in Vegetable Aratomy and Physiology under considerable difficulties owing to the small space available; lie has had to repeat all the work four times. The numbers attending his practical classes in the Michaelmas Term, 1882 , were 19 ; in the Lent Term, 1883, 37 ; in the present Easter Term, 35.

Prof. Hughes reports that the whole of the geological library, consisting of 800 volumes and Iooo pamphlets, of the late Mr. E. B. Tawney, have been liberally presented to the Woodwardian Museum by his brother, Mr. C. H. Tawney, late Fellow of Trinity College. Opportunity has been taken in the past year to largely improve the foreign Tertiary collections in the museum.

Prof. Stuart reports the addition of a number of machines and a large development of his classes; a foundry begun as an experiment has proved one of the most successful parts of his undertaking.

The Philosophical Library in the new Museums has been largely increased by the valuable presents made by the family of the late Prof. Balfour, by Mr. J. W. Clark, by Prof. Darwin, Prof. Humphry, Prof. Newton, and others.

It has been recommended by the Special Board for History and Archæology that a separate Board be created for Archæology, distinct from that of History. This has been concurred in by the General Board of Studies.

The Botanic Garden Syndicate have reported many improvements in the collections of trees, of rock vegetation, and in the Plant Houses. The largest specimens in the Palm House have been safely lowered to about $2 \frac{1}{2}$ feet below the ground level. All the genera of carnivorous plants in cultivation and most of the species are now in the collection. Vitis gongylodes has been flowered for the first time in this country. The Curator, Mr. Lynch, was deputed to visit the Botanic Gardens at Dublin,
Manchester, and Liverpool, and has also, visited Chatsworth with the result that much valuable information has been obtained in all departments of management and cultivation, and many important exchanges have been made.

The Adams Prize, for a general investigation of the action upon each other of two closed vortices in a perfect, incompressible fluid, has been awarder to Mr. J. J. Thomson, M.A., Fellow of Trinity College.

Messrs. W. H. Besant and E. T. Routh are the first to be notified as " approved by the general Board of Studies for the Degree of Doctor in Science."

Candidates for the Professorships of Physiology and Anatomy are requested to send their names to the Vice-Chancellor on or before june 7 .

THE Institute of Agriculture, South Kensington, will give an extended series of lectures next winter, beginning on October $\mathbf{r}$. The following courses are arranged for:-Mr. Bernard Dyer, Chemistry in Relation to the Soil ; Mr. F. Cheshire, Practical Course on the Use of the Microscope (these two courses to be delivered in the Lecture Theatre of the Museum of Geology, Jermyn Street). The next series will be given in the Lecture Room of the Natural History Museum, Sonth Kensington : Mr. Bettany, Vegetable Physiology; Mr. Worthington Smith, Diseases of Farm Crops; Prof. J. W. Axe, Animal Physiology in Relation to Farm Stock; Miss E. A. Ormerod, Farm In ects; Mr. W. Topley, Geology and Physical Geography in Relation to Agriculture. The remaining courses will be given in the Lecture Theatre of the South Kensington Museum : Prof. Tuson, the Chemistry of the Food of Farm Stock; Prof. Buckman, Farm Seeds; Prof. Tanner, Agriculture; Mr. R. Holland, Management of Grass Land ; Mr. Gilbert Murray, Breeding and Management of Horses; Mr. W. Housman, Cattle; Mr. H. Woods, and Mr. J. A. Clarke, Sheep; Prof. J. W. Axe, Preventable Diseases of Farm Stock; Farm Implements and Machinery, Mr. W. R. Bousfield and Mr. W. W. Beaumont. A distinct course of lectures will be given on Poultry, Dairy, and Bee Management. The arrangements made enable students to give their undivided attention to one subject at a time, two lectures being given daily till the subject is completed. The fees being at the rate of half a guinea for each week's course of ten lectures, and any student being allowed to at tend a single course, the greatest facility exists for persons choosing their work accord. ing to their needs or convenience. Thus it is believed, after the success of the tentative courses of the past winter, that many sons of tenant farmers will find this a most valuable and available mode of acquiring an agricultural education.

\section{SCIENTIFIC SERIALS}

THE American Naturalist for March, I883, contains :-On the extinct dogs of North America, by E. D. Cope.-On the plains of Michigan, by V. M. Spalding.-Organic physics, by Charles Morris.-Indian music, by E. A. Barber.-On the occurrence of fossiijferous strata in the lower Ponent (Catskill) group of Middle Pennsylvania, by E. W. Claypole.-Pitcher plants, by Joseph F. James.

April, I833, contains :-The Naturalist Brazilian Expedition, No. I, from Rio de Janeiro to Porto Alegre, by H. S. Smith.Unnatural attachments among animals, by J. D. Caton.-Butterfly hunting in the desert, by W. G. Wright.-The extinct Rodentia of North America, by E. D. Cope.-Hetero enetic development in Diaptomus, by C. L. Herrick.-A study of the immature plumage of the North American sbrikes to show their descent from a common progenitor, by Thos. H. Streets.

May, 1883 , contains :-Wampum and its history, by E. Ingersoll. - The Naturalist Brazilian Expedition, No. 2, by H. S. Smith. - The Polar organisation of animals, by C. Morris.-On the classification of moths, by A. R. Grote.-Heterovenetic development of Diaptomus, by C. L. Herrick.-On the morphology of arteries, especially those of the limbs, by F. Baker. -The hairy woodpecker, by A. G. Van Aken.

Archives Italiennes de Brologie, tome ii. fasc. 2, November 30 , I882, contains among the original articles the following:-On the minute anatomy of the muscles which move the wings of insects, by G. V. Ciaccio.-On the structure of striated muscular fibre in some vertebrates.-On the development and the morphology of the kidney of osseous fish, by C. Emery.-On the substance preventing the coagulation of the blood and lymph whilst these contain peptone, by Jules Fano.-On the germs and lower 